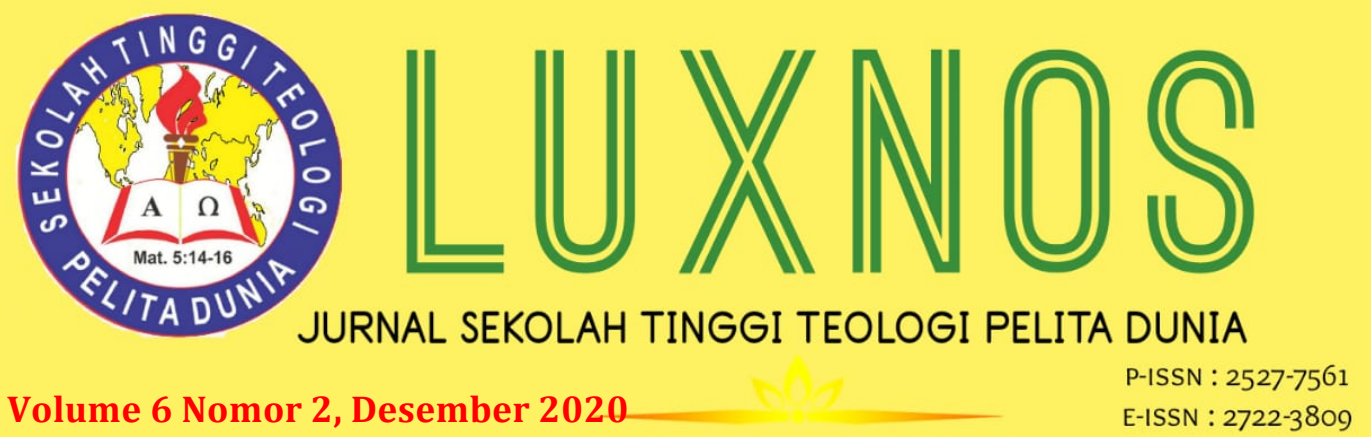

\title{
Tinjauan Teologis Realisasi Perintah Jangan Mencuri Dalam Keluaran 20: 15 Berdasarkan Perspektif Sejarah Penebusan
}

\author{
Made Nopen Supriadi ${ }^{1}$, \\ Sekolah Tinggi Teologi Injili Arastamar Jakarta ${ }^{1}$, \\ madenopensupriadi@gmail.com \\ Iman Kristina Halawa ${ }^{2}$, \\ Sekolah Tinggi Teologi Arastamar Bengkulu² \\ imankristinahalawa@sttab.ac.id,
}

\section{Regueli Daeli ${ }^{3}$}

Sekolah Tinggi Teologi Arastamar Bengkulu ${ }^{3}$ reguelidaeli@gmail.com

\begin{abstract}
The purpose of the theological review of the commandments in Exodus 20:15 is to expand to understand the commandment not to steal in a future context. The method of theological review uses a redemptive-historical perspective centered on the work and person of Jesus Christ. So this paper exPerjanjian Lamaains how the realization of the eighth law in the life of Jesus Christ and at His second coming. Furthermore, this paper will show that there are developments and changes in the realization of the commands in Exodus 20:15 in the context of the Old Testament, New Testament, present, and eternal life in the new heaven and earth. The theological review of the
\end{abstract}

${ }^{1}$ Made Nopen Supriadi menyelesaikan pendidikan Sarjana Teologi (S.Th) di STT Ebenhaezer, Tanjung Enim pada tahun 2014, saat ini sedang menempuh studi Pasca Sarjana pada program Magister Teologi (M.Th) di Sekolah Tinggi Theologia Injili Arastamar (SETIA) Jakarta, aktif menulis artikel Jurnal, Buku-buku Teologi Kristen, Prosiding Bahan Ajar dan Seminar serta sebagai Pengelola Jurnal Manna Rafflesia di Sekolah Tinggi Teologi Arastamar Bengkulu (STTAB).

2 Iman Kristina Halawa menyelesaikan pendidikan Sarjana Teologi (S.Th) di Sekolah Tinggi Teologi Arastamar Bengkulu (STTAB) pada tahun 2013, menyelesaikan pendidikan Magister Teologi (M.Th) di Sekolah Tinggi Theologia Injili Arastamar (SETIA) Jakarta pada tahun 2019, Dosen tetap di STTAB dalam bidang Teologi Biblika secara khusus Perjanjian Lama.

${ }^{3}$ Regueli Daeli adalah Mahasiswa Semester V, Program Sarjana Teologi (S.Th) di Sekolah Tinggi Teologi Arastamar Bengkulu (STTAB), dengan prestasi akademik mendapatkan Juara 2 Nasional dalam perlombaan membaca Bahasa Ibrani yang diselenggarakan oleh STBI Semarang pada Oktober 2020. 
realization of the commandments in Exodus 20:15 to affirm the immutable and unchanging princiPerjanjian Lamaes of God's Word, even though there are changes in form in its realization from time to time. Thus, this paper reveals what the Bible describes the realization of the eighth law in the past and the present, but for the future.

Keywords: Realization, the command, Do Not Steal, History of Redemption

\begin{abstract}
Abstrak: Tujuan tinjauan teologis perintah dalam Keluaran 20: 15 sebagai pengembangan untuk memahami perintah jangan mencuri dalam konteks masa yang akan datang. Metode peninjauan teologis menggunakan perspektif sejarah penebusan yang berpusat pada karya dan pribadi Yesus Kristus. Sehingga tulisan ini menjelaskan bagaimana realisasi hukum kedelapan dalam kehidupan Yesus Kristus dan pada saat kedatangan-Nya yang kedua. Selanjutnya tulisan ini akan menunjukkan adanya perkembangan dan perubahan realisasi perintah dalam Keluaran 20:15 pada konteks Perjanjian Lama, Perjanjian Baru, masa kini dan pada masa kehidupan kekal di langit dan bumi yang baru. Tinjauan teologis realisasi perintah dalam keluaran 20 : 15 untuk menegaskan prinsip Firman Allah yang kekal dan tidak berubah, meskipun ada perubahan bentuk dalam realisasinya dari masa ke masa. Dengan demikian tulisan ini mengungkapkan apa yang dipaparkan Alkitab mengenai realisasi hukum kedelapan pada masa lampau dan masa kini, tetapi sampai kepada masa yang akan datang.
\end{abstract}

Kata Kunci: Realisasi, Perintah, Jangan Mencuri, Sejarah Penebusan

\title{
Pendahuluan
}

Pemikiran teologis Perjanjian Lama merupakan pokok penting dalam melakukan pendekatan terhadap teks-teks Perjanjian Lama. Beberapa pakar menyetujui bahwa istilah "perjanjian" menjadi kata kunci yang menghubungkan dan menyatukan seluruh Alkitab. Gerhard F. Hasel menuliskan bahwa merumuskan pemikiran teologis Perjanjian Lama melibatkan hubungan timbal balik antara Perjanjian Lama dan Perjanjian Baru, beragam tema dapat muncul sebagai bahan pertimbangan untuk merumuskan pemikiran teologis Perjanjian Lama, diantaranya kepemimpinan Allah, umat Allah, Pemilihan, Perjanjian, penghakiman, keselamatan, penciptaan dan penciptaan baru. ${ }^{4}$ Penelitian ini didasarkan pada prinsip dari Willem VanGemeren yang menggunakan metode pendekatan sejarah penebusan, ia menuliskan pendekatan sejarah penebusan begitu memperhatikan teks, periode khusus sejarah penebusan dan hubungan antara periode itu dengan kedatangan Yesus sebagai Juruselamat dan pemulihan langit dan bumi. Prinsip pendekatan sejarah penebusan bersifat Kristologis sekaligus eskatologis, sehingga sejarah dari penciptaan sampai ke pemulihan bersifat progressif. Penebusan bukanlah pembebasan dari dunia materi, namun membangun kembali dan menguduskan dunia

${ }^{4}$ Gerhard F. Hasel, Teologi Perjanjian Lama, Revisi. (Malang: Gandum Mas, 2006), 167. 
materi.Penulis mengamati kajian terhadap hukum jangan mencuri dalam Keluaran 20: 15 masih banyak bersifat praktis dan belum terlihat pengkajian relevansi hukum dalam Keluaran 20: 15 dalam konteks penggenapan sejarah penebusan yaitu pada kedatangan Yesus Kristus kedua kali (paraousia) dan orang percaya yang hidup di dalam langit dan bumi yang baru. ${ }^{5}$ Kurangnya kajian pada konteks eskatologi adalah dasar dari penelitian ini. Penulis mengamati bahwa jika sebuah hukum tidak dimengerti relevansinya pada masa yang datang maka akan ada masalah dalam implementasi hukum tersebut di masa kini dan di masa yang akan datang. Penulis menilai jika hukum kedelapan tidak memiliki kejelasan makna di masa yang akan datang, serta implikasi hukum tersebut tidak dimengerti dengan baik secara eskatologis maka hukum kedelapan hanya akan menjadi sebuah hukum yang kehilangan kekuatan relevansi. Oleh karena itu penelitian ini untuk menjawab bagaimanakah relevansi hukum kedelapan pada konteks penggenapan sejarah penebusan.

Penelitian ini juga didasarkan pada pendalaman konsep tentang penggenapan Yesus atas hukum Taurat, secara khusus penggenapan Yesus terhadap hukum kedelapan. David Wenham menuliskan bahwa penggenapan Yesus terhadap Hukum Taurat dalam segala aspek, baik pelaksanaan serta penggenapan penghukuman bagi orang pilihan yang gagal melakukan hukum Taurat. ${ }^{6}$ Finalitas Pemahaman terhadap pribadi dan karya Yesus Kristus adalah bagian yang sangat penting pada penelitian ini. Penulis menemukan beberapa kasus kesalahpahaman terhadap personalitas Yesus yang memberikan tuduhan Yesus sebagai pencuri dan tuduhan Yesus sebagai pencuri dengan melakukan tafsiran terhadap teks-teks Alkitab dengan tidak benar. ${ }^{7}$ Kedua kesalahan tersebut menghasilkan kesimpulan bahwa Yesus hanyalah manusia berdosa dan tidak sempurna. Tulisan ini akan menjawab kesalahpahaman konsep

${ }^{5}$ Mengenai hal ini dapat melihat pada beberapa tulisan dari Philip C. Johnson (Lih.:Philip C. Johnson, "Keluaran," in The Wyclife Bible Commentary, 1st ed., vol. 1, 3 vols. (Malang: Gandum Mas, 2011), 204.), Budi Asali (Lih.:Budi Asali, “10 Hukum Tuhan: Hukum Kedelapan,” golgothaministry.org, $\begin{array}{llll}\text { Golgotha Ministry, } & \text { November } & \text { 13, } & \text { 2020, }\end{array}$ http://www.golgothaministry.org/artikel/pengajaran_10hukum08.htm.), Iman Nuel Zai dan Thuan Ong (Lih.: Iman Nuel Zai and Thuan Ong, "Memahami Konsep Penebusan Dalam Hukum Taurat Dan Penggenapannya Dalam Diri Yesus Kristus," Pondok Daud: Jurnal Teologi Kristen 6, no. 1 (2020): 1-7, http://ejournal.sttpk-medan.ac.id/index.php/pondokdaud/article/view/3/2.) dan Muriwali Yanto Matalu (Lih.: Muriwali Yanto Matalu, Dogmatika Kristen, last Edition (Malang: GKKR, 2017), 773.)

6David Wenham, "Jesus and the Law: An Exegesis on Matthew 5: 17-20," Themelios 4, no. 3 (1979): 92-96.

${ }^{7}$ Matius 21: 1-7, Markus 11: 1-7 dan Lukas 19: 29-34 oleh kelompok tertentu menuliskan bahwa Yesus melakukan pencurian keledai (Lih. :Kafirun Murtadin, "Yesus Maling Keledai," .com, Murtadinkafirun, last modified February 10, 2011, accessed September 5, 2020, https://murtadinkafirun.forumotion.com/t12990-yesus-maling-keledai.) Selanjutnya syair sebuah group band bernama violent soho, membuat judul lagu "Jesus Stole." Dalam syair tersebut menunjukkan bahwa Yesus dikatakan sebagai pencuri pasangannya (Lih. :Violent Soho, Violent Soho Jesus Stole My Girlfriend, You Tube, Music (UMG Recordings, n.d.), accessed September 5, 2020, https://www.youtube.com/watch?v=kzrAfkyq-xM.) 
tersebut dengan menunjukkan bahwa Yesus Kristus tidak melanggar hukum kedelapan.

Penelitian ini juga didasarkan pada penggalian penulis mengenai kedatangan Tuhan Yesus telah menghadirkan Perjanjian yang Baru. Yesus Kristus merealisasikan penggenapan seluruh tuntutan Hukum Taurat di dalam diri-Nya dengan sempurna (Lih. Mat. 5: 17; Rom. 8: 3, Gal. 3: 13; 4: 4-5Ef. 2: 14-16).Hukum Taurat menerapkan salah satu perintah yaitu larangan 'jangan mencuri' (Lih. Kel. 20: 15), yang juga dikenal dengan hukum kedelapan.Tulisan ini akan menganalisis bagaimanakah posisi hukum kedelapan setelah Yesus Kristus menggenapi seluruh Hukum Taurat?. Apakah Hukum kedelapan masih perlu direalisasikan pada masa kini?.Tulisan ini akan memberikan kajian bagaimana realisasi atau perwujudnyataan pelaksanaan hukum kedelapan dalam kehidupan umat Kristen di Perjanjian Baru setelah penggenapan Hukum Taurat oleh Yesus Kristus dan bagaimana realisasi hukum kedelapan dalam konteks puncak sejarah penebusan yaitu pada kedatangan Tuhan Yesus yang kedua kali di dalam langit dan bumi yang baru?. Dengan demikian tulisan ini akan memberikan kajian adanya kesinambungan realisasi hukum kedelapan dari penggenapan Yesus Kristus sampai pada konteks kedatangan-Nya yang kedua kali.

\section{Metode Penelitian}

Penelitian ini menggunakan metode deskriptif analisis yang mengumpulkan data-data penelitian melalui sumber-sumber tulisan yang berkaitan dan memberikan deskripsi. ${ }^{8}$ Tinjauan teologis realisasi hukum ke delapan berdasarkan pendekatan sejarah penebusan(redemptive-historical approach) artinya melihat sejarah Alkitab dalam konsep penebusan Yesus, meskipun ada yang mengelompokkan metode ini sebagai model pendekatan non prakritis, ${ }^{9}$ namun metode ini justru memberikan stimulasi berpikir ktitis kepada para teolog untuk menjelaskan sebuah teks pada konsep penebusan Kristus. Herman N. Ridderbos menyatakan,"The redemptivehistorical character of the New Testament authority."10Meskipun sejarah penebusan karakter dalam Perjanjian Baru, namun sejarah penebusan menjadi sebuah

${ }^{8}$ Mohamas Nazir, Metode Penelitian (Jakarta: Ghalia Indonesia, 1998), 64.

${ }^{9}$ Bdg. Dengan Emauel Gerrit Singgih, yang menuliskan ada banyak metode dalam memahami Alkitab, yaitu 1). Model non/prakkritis, model ini dikontrol oleh sistem ajaran / teologi. 2). Model kritis-historis, model ini berusaha melepaskan diri dari sistem ajaran / teologi tertentu, meskipun dalam kenyataan sulit berbuat seperti itu. 3). Model Kritis-Literer, membandingkan berbagai terjemahan. 4). Model reader's response, model ini menekankan bukan hanya teks yang penting, melainkan pembaca juga sama pentingnya (Lih: Emanuel Gerrit Singgih, Dua Konteks: Tafsir-Tafsir Perjanjian Lama Sebagai Respons Atas Perjalanan Reformasi Di Indonesia (Jakarta: BPK Gunung Mulia, 2009), X-Xii.)

${ }^{10}$ Herman N Ridderbos, Biblical and Theological Studies, Redemptive History and The New Testament Scriptures (Philipsburg: Presbyterian and Reformed Publishing Company, n.d.), 49. 
paradigma baru dalam memahami keseluruhan Alkitab, dengan demikian pendekatan sejarah penebusan memiliki relevansi dalam memahami teks-teks Perjanjian Lama.

Louis Berkhof menuliskan bahwa Perjanjian Baru adalah sebuah tafsiran atas isi Perjanjian Lama, Perjanjian Lama adalah bayangan yang merepresentasikan realitas spiritual yang dihadirkan dan digenapi dengan sempurna dalam terang Perjanjian Baru. Pandangan Berkhof menunjukkan bahwa teks Perjanjian Lama diterangkan dan dijelaskan dalam PB. ${ }^{11}$ Dengan demikian banyak narasi dalam Perjanjian Lama tidak hanya difokuskan dalam segi moralitas, tetapi lebih sebagai penyataan Mesias yang akan datang. Narasi Perjanjian Lama berfungsi sebagai tipe dan bayangan yang menunjukkan sejarah tentang Mesias, yang penggenapannya dinyatakan dalam pribadi dan karya Yesus Kritus. ${ }^{12}$

Prinsip Teologis pendekatan sejarah penebusan didasarkan pada Lukas 24:27, 44 yang menyatakan bahwa seluruh Kitab Suci, mulai dari kitab Taurat Musa, kitab nabi-nabi dan kitab Mazmur menuliskan tentang Yesus Kristus. Sidney Greidanus memberikan makna bahwa Lukas 24: 27, 44 dengan istilah redemptive-historicalChrictocentris, selanjutnya Greidanus menjelaskan prinsip tersebut menekankan bahwa seorang pengkhotbah wajib mencermati bagaimana para penulis Perjanjian Baru menghubungkan tulisan-tulisan mereka dengan Perjanjian Lama dan panduan normatif serta terbaik untuk mengkhotbahkan Kristus dari Perjanjian Lama adalah Perjanjian Baru. ${ }^{13}$ Dengan demikian pendekatan sejarah penebusan adalah salah satu metode penafsiran sejarah Alkitab di dalam konteks sejarah penebusan yang berpusat kepada Yesus Kristus.

11"Berkhof menuliskan: "The new testament is a commentary on the Old. While the Old Testament contains but a shadowy representation of spiritual realities, the new testament presents them in the perfect light of fulness of time" (Lih.: Louis Berkhof, PrinciPerjanjian Lamaes of Biblical Interpretation (Grand Rapids, 1981) 137.)

12 Willem VanGemeren, Progress Penebusan: Kisah Keselamatan Dari Penciptaan Sampai Yerusalem Baru (Surabaya: Momentum, 2016), 17-19. Bdg. Pemahaman Richard L. Pratt yang menuliskan: " Wahyu Perjanjian Lama menunjuk pada pemunculan-Nya. Yesus sendiri berkata, "Jikalau kamu percaya kepada Musa, tentu kamu akan percaya juga kepada-Ku sebab ia telah menulis tentang Aku" (Yoh. 5:46) dan "Abraham bapamu bersukacita bahwa ia akan melihat hari-Ku dan ia telah melihatnya dan ia bersukacita" (Yoh. 8:56). Wahyu Perjanjian Baru dibagun di atas signifikansi kedatangan Kristus. Seperti Paulus meringkas kerasulannya, "kami memberitakan Kristus yang disalibkan" (1Kor. 1:23). Dengan pengertian ini, Kristus adalah fokus seluruh sentral Alkitab" (Lih.: Richard L. Pratt, He Gave Us Stories (Surabaya: Momentum, 2005), 379.)

13 Prett menuliskan Kaum Protestan tradisional memandang sejarah penebusan dengan cara pandang seperti ini. Pengakuan iman dan Katekismus Utama telah memandang kedatangan pertana Kristus sebagai puncak agama Biblika. Secara tipikal, sejarah sebelum Kristus dikenal sebagai zaman "Taurat", dan dalam sejarah sesudah Kristus dikenal sebagai zaman "Injil". Sentralitas Kristus dalam sejarah keselamatan telah menjadi tonggak bagi theologi Kristen yang ortodoks (Lih.: Pratt, He Gave Us Stories, 379.) 


\section{Hasil Dan PEMBAHASAN}

Penelitian ini bertujuan untuk melakukan tinjauan teologis terhadap hukum kedelapan dalam perspektif sejarah penebusan. Sehingga pada pembahasan hukum ini akan memaparkan makna hukum kedelapan dalam Kitab Keluaran beradasarkan perkembangan konteks dimana teks Keluaran 20: 15 dikutip pada bagian Kitab yang lain sesuai dengan perkembangan sejarah. Hasil pembahasan ini akan memberikan penjelasan bagaimana Yesus menggenapi Hukum Kedelapan dalam kehidupannya selama di dunia. Penulis pada bagian ini memberikan jawaban terhadap beberapa keberatan tentang kasus-kasus di mana Yesus diduga gagal melakukan hukum kedelapan. Dengan demikian hasil pembahasan ini akan memberikan penjelasan tentang realisasi hukum kedelapan pada konteks masa kini dan masa yang akan datang, terutama pada puncak penggenapan penebusan oleh Yesus saat kedatanganNya yang kedua kali secara khusus pada konteks langit dan bumi yang baru.

\section{Definisi Jangan Mencuri}

Ungkapan 'jangan mencuri' dalam bahasa Ibrani "bngt al" (lō tḡanōb $\underline{b}$ ) yang artinya dia tidak akan mencuri. ${ }^{14}$ Bahasa Yunani menuliskan ungkapan 'jangan mencuri' yaitu 'Ouv kle,yeij' (ou klepseis) yang jika diterjemahkan memiliki arti yang sama yaitu 'dia tidak akan mencuri. '15 Page H. Kelley menjelaskan bahwa jika perintah negatif disertai dengan kata kerja imperfek, maka hal tersebut menunjukkan sebuah larangan mutlak atau sebagian. ${ }^{16}$ Dengan demikian secara harfiah hukum tersebut menunjukkan sebuah larangan jangan mencuri yang bersifat mengikat dan dilakukan tanpa akhir. Ungkapan 'jangan mencuri' menunjukkan makna jangan mengambil hak milik orang lain tanpa seijin pemilik. Meskipun secara definitif ungkapan jangan mencuri terbatas pada unsur materi dan kepemilikan, namun secara prinsip ungkapan tersebut dapat melampaui konteks yang materi.

\section{Realisasi Hukum Kedelapan Dalam Perjanjian Lama}

14"bngt al" (lō tḡanōb) (Lih.: Karl Elliger and Wilhelm Rudolph, eds., Perjanjian Lama Ibrani Indonesia (Jakarta: LAI, 2016), 119.) Kata ' $l \bar{o}^{\prime}$ memiliki arti 'not'kata ini merupakan kata keterangan negatif yang artinya 'tidak, bukan dan jangan.(Lih. :Francis Brown, S.R. Driver, and Charles A. Briggs, eds., The New Brown Driver Briggs Gesenius Hebrew And English Lexicon With An Apendix Containing The Biblical Aramic (Lafayette: Associated Publishers And Authors. INC, 1978), 518.). Selanjutnya kata 'tḡanōb' kata ini ditulis dalam bentuk kata kerja yang belum selesai (verb qal imperfect), orang ke 2 maskulin tunggal, dari kata dasar 'bng' (ganab) yang memiliki makna 'steal'artinya 'mencuri, mencoleng, menyerobot dan membolos.' (Lih. : Ibid. 170.)

15'Ouv kle,yeij' (ou klepseis)(Lih. : Hasan Sutanto, Perjanjian Baru Interlinear Dan Konkordansi Jilid 1 (Jakarta: LAI, 2010), 108.)kata 'Ouv' merupakan kata particle negative yang artinya 'tidak, bukan dan jangan' kata ini ditulis sebanyak 1624 kali di PB (Lih. : Hasan Sutanto, Perjanjian Baru Interlinear Dan Konkordansi Jilid 2 (Jakarta: LAI, 2010), 585.). Kata 'kle,yeij' dituliskan dalam bentuk kasus future active indicative 2 singular ${ }^{15}$ dari kata dasar 'kle,ptw' (kleptō) yang artinya 'mencuri' kata ini ditulis sebanyak 13 kali dalam Perjanjian Baru (Lih. : Sutanto, Perjanjian Baru Interlinear Dan Konkordansi Jilid 2. 451.)

16Page H. Kelly, Ibrani Biblikal, 2nd ed. (Surabaya: Momentum, 2018), 187. 
Kitab-kitab Perjanjian Lama adalah tulisan yang difirmankan Allah, salah satu bagiannya adalah kelima Kitab yang ditulis Musa (Pentateukh). Kitab Keluaran terdapat di dalam Pentateukh, dalam kitab ini dicatat tentang pemberian sepuluh perintah Allah, salah satunya perintah 'jangan mencuri' (Kel. 20: 15). Tulisan ini membahas tentang hukum kedelapan. Perjanjian Lama menegaskan bahwa Allah adalah pemilik segala sesuatu, karena alam semesta dan isinya diciptakan-Nya. ${ }^{17}$ Alkitab memberikan catatan adanya tindakan mencuri yang dilakukan sebelum hukum kedelapan diberikan, hal tersebut terlihat dalam peristiwa Esau dan Yakub dimana Yakub melakukan pencurian dengan mengambil hak kesulungan Esau (Kej. 27: 18-40) dan Rahel mencuri terafim ayahnya (Kej. 31:19, 30), tindakan mencuri tersebut ditunjukkan dengan mencuri benda berharga dan mencuri hak pribadi.

Kejadian 15: 13-14 menyatakan Allah telah berfirman yang kepada Abraham tentang keadaan keturunannya yang akan berada di negeri asing, diperbudak dan dianiaya, namun Tuhan akan membebaskan dan memberikan harta benda yang sangat banyak, nubuat tersebut digenapi dalam konteks keturunan umat Israel yang berada di Mesir (Lih. : Kel. 1: 1-14). Keluaran 3: 21-22 menuliskan secara khusus suasana umat Israel yang akan bebas dari perbudakan, yaitu Tuhan akan membuat umat Mesir bermurah hati dan umat Israel akan merampasi harta benda umat Mesir. Keluaran 12: 35-36 merupakan realita dari proses keluarnya umat Israel dari Mesir, meskipun Allah membuat bangsa Mesir bermurah hati, namun tindakan umat Israel yang meminta dan cenderung untuk menguasai harta yang bukan miliknya, menunjukkan indikasikarakter bangsa Israel yang cenderung sulit untuk membatasi diri dari kerakusan(Bdg. Kel. 16:17-18; Bil. 11: 33-34). Dalam Amsal 6: 30-31 memberikan indikasi bahwa tindakan mencuri sebagai salah satu untuk memenuhi keinginan nafsu. Dengan demikian peristiwa pemberian hukum jangan mencuri oleh Allah di Gunung Sinai sebagai wujud antisipasi terhadap kecenderungan sikap kerakusan bangsa Israel yang berpotensi menguasai milik orang lain.

Dalam Keluaran 22: 1-9 memberikan rincian pelaksanaan hukum kedelapan. Hukum tersebut memberikan penjelasan bahwa bagi yang mencuri dihukum dengan memberikan ganti rugi. Hukum kedelapan dalam konteks Keluaran hanya sebagai aturan moral bagi bangsa Israel. ${ }^{18}$ Walter Eichrodt menekankan bahwa hukum ke delapan lebih dari sekedar menjaga milik pribadi, tetapi menentang segala bentuk

\footnotetext{
${ }^{17}$ Christie Kusnandar, "Sepuluh Perintah Tuhan Bagian Kedua: Kasih Terhadap Manusia Dalam Tinjauan Etika Kristen." 79.

${ }^{18}$ Bandingkan dengan pemahaman Fadilah Binti Uung Foeut yang menjelaskan pemahaman Hukum Kedelapan dengan Hukum ke sepuluh dan pemaparan yang diberikan hanya dari segi praktis.. (Fadilah Binti Ung Foeut, "Analisis Terhadap Konsep Dan Kedudukan Ten Commandements Dalam Agama YahudI" (UIN Sultan Syarif Riau, 2010), accessed September 5, 2020, http://repository.uinsuska.ac.id/10725/1/2010_201023PAG.pdf.)
} 
eksploitasi. ${ }^{19}$ Dengan demikian Allah mengingatkan umat Israel agar tidak berubah sikap sama seperti bangsa Mesir yang telah melakukan Perjanjian Lama eksploitasi.

Imamat 19 Tuhan kembali mengulangi prinsip-prinsip hukum yang diberikan kepada Musa di Gunung Sinai. Hukum kedelapan disebutkan sesudah Allah memberikan perintah agar meninggalkan hasil tanah yaitu buah yang berjatuhan untuk orang miskin dan orang asing (Lih. Im. 19: 9-10). Ayat ke-11 hukum kedelapan disebutkan kembali, hal tersebut menunjukkan bahwa tidak memberikan hak orang lain termasuk pelanggaran terhadap hukum kedelapan, selanjutnya konteks perintah kedelapan dibicarakan berkaitan dengan kekudusan hidup. Pada konteks ini tindakan mencuri bukan hanya mengambil milik orang lain tanpa ijin, tetapi seorang pemilik yang tidak memberikan hak atau bagiankepada orang lain dari apa yang dimiliknya juga merupakan pelanggaran. Pelanggaran terhadap hukum kedelapan juga berkaitan denganpersoalan kekudusan hidup. Dengan demikian hukum kedelapan dalam konteks Kitab Imamat mulai menekankan adanya nilai spiritualitas dan moral dalam pelaksanaan hukum kedelapan.

Ulangan 5: 19 Musa kembali mengulangi kembali hukum kesepuluh Firman. Dalam konteks ini bangsa Israel atau generasi baru akan memasuki tanah Kanaan. Musa mengulang hukum ini sebagai wujud peringatan agar bangsa Israel bisa membatasi diri dari keinginan dan hawa nafsu yang rakus pada waktu ingin memasuki tanah Kanaan. Dalam konteks Kitab Ulangan pemahaman bangsa Israel (generasi lama) terhadap hukum kedelapan sudah semakin kompleks. Musa melakukan pengulangan hukum Taurat lembali untuk para pendengar yaitu generasi baru (bdg. Ul. 5:3). Penulis menyakini Musa yang menyampaikan hukum Taurat dengan menggunakan tulisan-tulisan sebelumnya, demikian juga penjelasan terhadap hukum kedelapan tetap memiliki fungsi sebagai panduan spiritual dan moral. Anggus Paddison menjelaskan bahwa hukum Taurat adalah undangan untuk berpartisipasi ke dalam hidup sebagai umat Allah. ${ }^{20}$ Dengan demikian hukum kedelapan juga sebagai sepuluh hukum adalah hukum yang memiliki nilai prinsip secara universal. Hukum kedelapan menjadi salah satu bagian penting untuk menunjukkan identitas sebagai umat Allah.

Yosua 7:1-26 menunjukkan tindakan Akhan yang mengambil barang jarahan yaitu jubah yang indah buatan sinear. Pelanggaran yang dilakukan Akhan secara

19Walther Eichrodt, "The Law and the Gospel: The Meaning of the Ten Commandments in Israel and for Us," Interpretation: A Journal of Bible and Theology 11, no. 1 (January 1957): 23-40, accessed September 6, 2020, http://journals.sagepub.com/doi/10.1177/002096435701100102.

${ }^{20}$ Angus Paddison, "15th March: 3rd in Lent: The Resurrection and the Ten Commandments Exodus 20:1-17 Psalm 191 Corinthians 1:18-25 John 2:13-22," The Expository Times 120, no. 5 (February 2009): 243-245, accessed http://journals.sagepub.com/doi/10.1177/0014524608101114. 
prinsip masuk dalam kategori tindakan mencuri.Pelanggaran Akhan tersebut menyebabkan Tuhan murka dan dampaknya terjadi kegagalan bangsa Israel dalam menaklukan kota Ai. Pelanggaran Akhan sangat serius karena mengambil barangbarang yang dikhususkan bagi Tuhan, sehingga pelanggaran Akhan dalam mengambil barang yang dikhususkan bagi Tuhan sama dengan melanggar perjanjian kepada Tuhan (Lih. Yosua 6: 18-19 dan 7: 10-12). Yosua sudah memberikan peringatan kepada umat Israel agar tetap menjaga perjanjian kepada Tuhan dengan tidak mengambil barang-barang yang dikhususkan bagi Tuhan, hal tersebut menunjukkan antisipasi kepada umat Israel. Yosua memutuskan hukuman kepada Akhan dan keluarganya serta segala kepunyaannya dengan cara dilempari batu dan dibakar. Peristiwa tersebut menunjukkan terjadinya pola perubahan penghukuman terhadap kasus pencurian. Pada Kitab Keluaran 22:1-9 penghukuman tersebut hanya bersifat ganti rugi, namun pada konteks Yosua ini konsekuensi meningkat menjadi hukuman mati. Peningkatan tersebut terjadi akibat pelanggaran terhadap perjanjian kepada Allah (Yos. 6: 18-19). ${ }^{21}$ Pelanggaran Umat Israel terhadap perjanjian Allah, ditinjau secara prinsip teologis memiliki kaitan dengan kekudusan hidup (Lih. Im. 19), oleh karena itu tindakan mencuri melanggar perjanjian kepada Allah dan mencermarkan kekudusan umat Allah dan tindakan tersebut telah menjadi sebuah dosa.Komentar Calvin tentang hukum kedelapan menjelaskan bahwa hukum tersebut ditetapkan untuk jiwa dan tangan. ${ }^{22}$ Dengan demikian hukum kedelapan memiliki relasi terhadap kehidupan spiritualitas umat Israel, hukum ini terkait dengan perjanjian Allah kepada umat Israel, kekudusan hidup dan pelanggarannya adalah dosa serta konsekuensi semakin serius yaitu kematian.

Realisasi hukum kedelapan berkaitan dengan sejarah Kerajaan Israel. Peristiwa Daud dan Betsyeba menunjukkan ada beberapa hukum yang dilanggar oleh Daud, yaitu pelanggaran hukum mengingini istri orang lain Daud mengingini istri Uria, hukum perzinahan Daud berzinah terhadap Bertsyeba, Hukum berdusta Daus menyiapkan siasat untuk membunuh Uria dan Daud mengambil Betsyeba tanpa sepengetahuan Uria.Salah satu pelanggaran Daud secara prinsip adalah pelanggaran terhadap hukum kedelapan. ${ }^{23}$ Namun pada masa Daud belum ada realisasi hukum kedelapan dalam bentuk pencurian non materi. Penerapan hukum kedelapan hanya sebatas kasus pencurian dalam bentuk materi. Nabi Nathan ketika menegur Daud menggunakan gambaran seorang seorang kaya yang merampas kambing domba

\footnotetext{
21David M. Howard Jr, "Joshua," in The New American Commentary, ed. E. Ray Clendenen and Kenneth A. Mathews, vol. 5 (Nashville: Broadman \& Holman Publishers, 1998), 194.

${ }^{22}$ Yohanes Calvin, Institutio: Pengajaran Agama Kristen (Jakarta: BPK Gunung Mulia, 2011), 107.

${ }^{23}$ Moshe Garsiel, "The Story of David and Bathsheba: A Different Approach," The Catholic Biblical Quarterly 55, no. 2 (1993): 244-262.
} 
orang miskin (Lih. 2Sam. 12:1-4). Dalam perspektif Nabi Nathan, secara analogi Daud telah melakukan pelanggaran hukum kedelapan, meskipun perampasan itu bukan dalam bentuk materi.Meskipun ada unsur mencuri tetapi pada konteks ini belum ada ketetapan penghukuman terhadap tindakan mencuri yang bukan materi. Pemahaman terhadap hukum kedelapan masih direalisasikan pada konteks pencurian dalam bentuk materi.

Kitab-kitab Puisi memberikan penjelasan tentang prinsip hukum kedelapan. Ayub 1:17 menunjukkan peristiwa orang Kasdim merampas harta milik Ayub. Analisis tentang kisah Ayub, banyak pakar menyetujui sezaman dengan Abraham, dalam konteks yang lebih dekat yaitu Kejadian 14: 1-12 menceritakan kisah peperangan antara kerajaan yang di dalamnya terjadi perampasan harta benda, meskipun tidak ada catatan perampasan tersebut sebagai pelanggaran hukum, namun tindakan Abram yang mengalahkan para raja dan mengambil kembali harta benda serta Lot menunjukkan tindakan perampasan adalah sebuah tindakan pelanggaran moral. Selanjutnya dalam Kejadian 31: 19 pelanggaran Laban mencuri terafim ayahnya secara prinsip mengandung pelanggaran moral. Dalam konteks Ayub hukum kedelapan belum tertulis, meskipun demikian kisah Ayub memberikan indikasi bahwa perampasan termasuk tindakan yang salah. ${ }^{24}$ Dengan demikian peristiwa perampasan secara materi telah ada sebelum hukum kedelapan dituliskan.Asaf dalam Mazmur 50: 16-18menggambarkan pencuri sebagai sahabat dari orang fasik (bdg. Ams. 29:24).Amsal 30:9 ditulis oleh Agur bin Yake menunjukkan adanya potensi melakukan tindakan pencurian karena kemiskinan.Imamat 19 menuliskan bahwa mengambil hak orang sehingga menjadikannya miskin adalah pencurian. Calvin menuliskan agar orang Kristen jangan menjadi kaya dengan cara yang tidak adil. ${ }^{25}$ Dengan demikian dalam Kitabkitab Puisi menjelaskan ada sebuah kaitan antara kasus pencurian dengan pemilik harta. Pertama, kesalahan pemilik harta. Pencurian dapat terjadi jika pemilik yang kaya mengabaikan hak yang miskin. Saat kelompok yang miskin tidak memiliki kecukupan dan bagian mereka juga diambil oleh yang kaya maka berpotensi terjadi pencurian. Kedua, kerakusan pemilik harta. Pencurian terjadi karena manusia ingin memenuhi keinginannya untuk menguasai lebih daripada haknya. Ketiga, pencurian terjadi karena manusia dalam kemiskinan dan ingin memenuhi kebutuhan hidup yang mendesak.

${ }^{24}$ M.N. Supriadi, Menghadapi Relativitas Kehidupan: Sebuah Refleksi Kehidupan Ayub Dalam Penderitaan (Ayub 1:1-5; 13-22, 2:7-10, 42:10-17) (Permata Rafflesia, 2020), 10. https://books.google.co.id/books?id=mznJDwAAQBAJ.

${ }^{25}$ Calvin, Institutio: Pengajaran Agama Kristen, 105. 
Para Nabi di Perjanjian Lama menegur tindakan mencuri (Lih. Yer. 7: 9; 23: 30; Hos. 4: 2, Ob. 1: 5). Dalam Yeremia 23: 30 tindakan mencuri diterapkan dalam konteks para nabi palsu yang mencuri firman Tuhan. Yeremia memahami bahwa hukum kedelapan bukan hanya menyangkut tindakan pencurian secara materi tetapi dalam bentuk bukan materi, Yeremia 1:23 menunjukkan teguran Yeremia terhadap para pemimpin yang bersekongkol dengan pencuri, menerima suap dan sogok (bdg. Hos. 7: 1). ${ }^{26}$ Yeremia menggunakan ilustrasi malunya seorang pencuri yang tertangkap, untuk menggambarkan penduduk Yerusalem yang menduakan Tuhan dengan berhala. Sikap pencuri digambarkan Yeremia sebagai perusak (Lih. Yer. 49: 9). Kitab Yoel 2: 9 menggunakan perumpamaan hari Tuhan seperti pencuri yang datang menyerbu kota, meskipun tidak ada kaitan dengan hukum kedelapan, perumpaan tersebut menunjukkan bahwa pencurian adalah tindakan yang dilakukan tanpa sepengetahuan tuan rumah sehingga digambarkan sebagai suasan yang mengejutkan. Kitab Obaja memberikan gambaran bangsa Edom yang merasa aman dari penggeledahan dan pencurian pada malam hari (Lih. Ob. 1: 5-6). Kisah tersebut menyatakan bahwa Edom akan mengalami kehilangan atau kejatuhan akibat kesombongannya dengan cara yang tidak wajar. Dengan demikian kasus pencurian kepada bangsa Edom menunjukkan salah satu cara yang Allah telah tetapkan dalam memberikan penghukuman kepada bangsa Edom akibat dosa kesombongan (Lih. Ob. 1: 3) dan kekerasan terhadap saudara sebangsa yaitu Israel (Lih. Ob. 1:10).

Penjelasan di atas merupakan konteks para Nabi sebelum pembuangan Israel ke Babel pada tahun 586 SM. ${ }^{27}$ Setelah 70 tahun Israel kembali dari pembuangan, namun pelanggaran terhadap hukum kedelapan masih terlihat.Dalam Maleakhi 3:10 memberikan teguran karena adanya indikasi pencurian yang dilakukan umat Israel yang telah pulang dari pembuangan. Tindakan tersebut ditunjukkan dengan tidak memberikan hak yaitu persepuluhan untuk perbendaharaan di rumah Tuhan. Sikap tidak memberikan hak untuk perbedaharaan Bait Suci menunjukkan tindakan mencuri. Namun dari segi konsekuensi tidak ada tindakan serius yang diberikan secara moral dan sosial kepada para pelanggar. ${ }^{28}$ Jadi perkembangan realisasi hukum kedelapan dalam konteks umat Israel yang baru pulang dari pembuangan telah kembali melonggar.

${ }^{26}$ Kathleen M. O'connor, “The Prophet Jeremiah and Exclusive Loyalty to God," Interpretation: A Journal of Bible and Theology 59, no. 2 (April 2005): 130-140, accessed September 6, 2020, http://journals.sagepub.com/doi/10.1177/002096430505900203.

${ }^{27}$ Walter E. Rast, "Book Review: Isaiah and the Deliverance of Jerusalem A Study of the Interpretation of Prophecy in the Old Testament," Interpretation: A Journal of Bible and Theology 35, no. 4 (October 1981): 423-424, accessed September 6, 2020, http://journals.sagepub.com/doi/10.1177/002096438103500414.

${ }^{28}$ J.T. Marshall, "The Theology of Malachi," The Expository Times 7, no. 3 (December 1895): $\begin{array}{lcc}\text { 125-127, } & \text { accessed } & \text { September } \\ \text { http://journals.sagepub.com/doi/10.1177/001452469500700308. }\end{array}$ 


\section{Realisasi Hukum Ke Delapan Dalam Perjanjian Baru}

Alkitab menyatakan bahwa Yesus adalah penggenap seluruh hukum Taurat, baik dalam tindakan dan juga penggenap penghukuman bagi kegagalan orang percaya yang gagal melakukan Hukum Taurat (Mat. 5: 17; Rom. 4: 25; 5: 18-19; 7: 34; Gal. 3: 13-14; 1Ptr. 2: 22-25). Matius 5: 17 menyatakan: "Janganlah kamu menyangka, bahwa Aku datang untuk meniadakan hukum Taurat atau kitab para nabi. Aku datang bukan untuk meniadakannya, melainkan untuk menggenapinya." Homer A. Kent menjelaskan ayat tersebut merupakan tanggapan Kristus terhadap Perjanjian Lama dengan menaati Hukum Taurat secara sempurna, menggenapi semua lambang dan nubuatnya serta menjalani sepenuhnya hukuman dari Hukum Taurat selaku pengganti orang-orang berdosa (Rom. 3: 20-26; 10: 4). ${ }^{29}$ Dengan demikian hukum kedelapan yang merupakan salah satu bagian dari Hukum Taurat juga digenapi oleh Yesus Kristus.

Pada tulisan ini memberikan fokus terhadap realisasi yang telah dilakukan oleh Yesus melalui kehidupan baik pribadi dan karya-Nya dalam menggenapi hukum kedelapan. ${ }^{30}$ Matius 6:19 menyatakan bahwa Yesus menjelaskan tentang hal mengumpulkan harta, di dalam penjelasan tersebut Yesus menggunakan gambaram pencuri yang dapat mencuri harta di dunia. Tuhan Yesus menunjukkan bahwa tindakan mencuri ialah mengambil harta milik orang lain tanpa izin. Kitab Injil memberikan catatan, Yesus kembali mengulas sepuluh hukum (Lih. Mat. 19: 18, Mar. 10: 19, Luk. 18: 20). Matius 19: 16-22 menuliskan kisah Pemuda kaya bertanya tentang perbuatan baik untuk memperoleh hidup kekal. Yesus memberikan jawaban yaitu dengan menuruti perintah Allah, salah satu perintah tersebut adalah jangan mencuri. Pemuda tersebut telah melakukannya dan bertanya apa yang masih kurang. Yesus memberikan perintah untuk menjual hartanya dan mengikut-Nya, jika ia hendak sempurna. Perkataan Yesus tersebut bukan berarti Pemuda tersebut tidak boleh memiliki kekayaan, tetapi Yesus mengetahui kekurangan dari Pemuda tersebut adalah keterikatan terhadap harta yang membuat perwujudan kasih kepada Tuhan dan sesama tidak terealisasi. Dengan demikian perkataan Yesus menunjukkan bahwa pemuda tersebut masih memiliki kegagalan dalam melaksanakan inti dari Hukum Taurat yaitu kasih kepada Tuhan dan sesama. ${ }^{31}$ Yesus membukakan sebuah konsep bahwa tindakan lahiriah dalam melakukan hukum Taurat tanpa kasih tidak ada artinya (Bdg. 1Kor. 13:3). Hal tersebut sesuai dengan pengajaran Yesus tentang

${ }^{29}$ Homer A. Kent, "Matius," in The Wycliffe Bible Commentary, ed. Everett F. Harrison and Charles F. Pfeiffer, vol. 3, 3 vols. (Malang: Gandum Mas, 2008), 35.

30David S. Cairns, "The Person of Jesus Christ," The Expository Times 24, no. 3 (December 1912): 104-109, accessed September http://journals.sagepub.com/doi/10.1177/001452461202400302.

31Kent, "Matius" 89. 
hukum yang terutama yaitu mengasihi Tuhan dan mengasihi sesama (Lih. Mat. 22: 34-40). ${ }^{32}$ Pengajaran Yesus tentang hukum mencuri dikaitkan tindakan yang timbul dari hati dan menajiskan orang (Lih. Mat. 15:18-19; Mar. 7:20-23).

Tindakan mencuri adalah hal yang negatif, namun Tuhan Yesus menjadikan konsep tentang pencuri sebagai gambaran kedatangan-Nya kedua kali (Mat. 24: 4344; Luk. 12:39-40; bdg. Yoel 2: 9). Para rasul memberikan contoh yang sama dalam mengajarkan tentang hari Tuhan yang akan datang seperti pencuri pada malam hari, perumpamaan ini sama dengan pengajaran Yesus Kristus, hal tersebut menekankan bahwa manusia hendaknya hidup di dalam terang dan selalu berjaga-jaga secara rohani (Lih. 1Tes. 5: 1-11; 2Ptr. 3: 10, Why. 3: 3 \& 16: 15). Namun terlepas dari konteks eskatologis, Penulis hanya ingin menunjukkan bahwa Yesus Kristus dan para rasul pada dasarnya memiliki pemahaman bahwa seorang pencuri adalah orang yang mengambil harta sesamanya dengan diam-diam dan tanpa sepengetahuan pemilik.

Dalam Yohanes 10: 1-18 Tuhan Yesus memberikan perbandingan antara gembala yang baik dan pencuri. Herman N. Ridderbos menjelaskan ungkapan 'semua orang yang datang sebelum Aku adalah pencuri-pencuri dan perampok-perampok' menunjuk kepada degradasi umum dari kepemimpinan rohani di Israel, yang sering dijelaskan di Perjanjian Lama (Yeh. 34; Mat. 9: 35). ${ }^{33}$ Everett F. Harrison dan Donald Guthrie memiliki pandangan yang sama bahwa istilah pencuri menunjuk kepada para pemimpin rohani Yahudi yang tidak berintegritas, sehingga suara mereka tidak lagi didengarkan, pandangan tersebut sama-sama merujuk dari cara orang Farisi memperlakukan orang yang buta sejak lahirnya bagaikan gembala-gembala asing terhadap kawanan Domba Allah. ${ }^{34}$ Eichrodt menuliskan bahwa sebagai penggenap hukum Taurat, maka Yesus harus melakukan hukum tersebut dengan sempurna. ${ }^{35}$ Pernyataan Eichrodt tersebut memerlukan tinjauan terhadap kehidupan Yesus dalam Kitab-Kitab Injil. Dalam pelayanan Yesus ada banyak tindakan Yesus membawa orang-orang menerapkan hukum kedelapan. Perubahan hidup Matius pemungut cukai (Mat. 9: 9-13) dan Zakheus kepala pemungut cukai (Luk. 19: 1-10) menunjukkan Yesus bukan hanya tahu hukum kedelapan dan menerapkannya secara pribadi, tetapi Yesus membawa orang-orang yang dilayaninya ikut juga mengimplementasikan pengajaran hukum kedelapan. Meskipun Yesus mampu melakukan hukum kedelapan dan membawa orang lain melakukannya, tidak ada

\footnotetext{
32Wenham, "Jesus and the Law," 92-96.

${ }^{33}$ Herman N Ridderbos, Injil Yohanes Suatu Tafsiran Theologis (Surabaya: Momentum, 2012), 388-39.

${ }^{34}$ Everett F. Harrison, "Yohanes," in The Wycliffe Bible Commentary, ed. Charles F. Pfeiffer, vol. 3, 3 vols. (Malang: Gandum Mas, 2008), 354.Dan Donald Guthrie, "Yohanes," in Tafsiran Alkitab Masa Kini, trans. W.B. Sijabat, vol. 3 (Jakarta: YKBK, 1994), 302.

35Eichrodt, "The Law and the Gospel," 23-40.
} 
indikasi Yesus menekankan bahwa semua orang harus mampu melakukan hukum Taurat dengan sempurna. Dengan demikian tindakan Yesus yang mampu mengubahkan Matius dan Zakheus menunjukkan bahwa integritas Yesus secara rohani menunjukkan bahwa Yesus adalah gembala yang baik, hal tersebut bertentangan dengan para pencuri atau prampok. Yesus menunjukkan bahwa seorang pemimpin agama yang tidak mengajar firman Tuhan dengan benar dan tidak menunjukkan integritas rohani adalah seorang pencuri secara rohani.

Dalam pelayanan Yesus secara khusus pada waktu Yesus akan dielu-elukan di Yerusalem (Mat. 21:1-9; Mar. 11: 1-10; Luk. 19:28-37 dan Yoh. 12: 12-15). Yesus menyuruh dua orang muridnya untuk mengambil keledai yang tertambat untuk ditunggangi. Tindakan Yesus tidak menunjukkan pelanggaran terhadap hukum kedelapan, karena keledai tersebut akan dikembalikan. ${ }^{36}$ Merill C. Tenney menuliskan bahwa "Yesus pasti sudah mempunyai kesepakatan dengan pemilik keledai itu bahwa Ia bisa menggunakan hewan tersebut kapan saja Ia mau". ${ }^{37}$ Dengan demikian isu teologis yang menyatakan Yesus melakukan tindakan mencuri pada kasus ini tidak terbukti. Yesus juga dalam pelayanan mengajarkan agar memberikan hak kepada yang berhak. Hal tersebut dilakukan Yesus pada waktu Ia menjawab pertanyaan mengenai pembayaran pajak kepada Kaisar, Yesus mengajarkan bahwa untuk memberikan apa yang wajib diberikan kepada Kaisar dan kepada Allah (Lih. Mat. 22: 15-22; Mar. 12: 13-17; Luk. 20: 20-26). Dengan demikian secara praktis Yesus melakukan hukum kedelapan dengan tepat. Kesempurnaan Yesus dalam menggenapi hukum kedelapan diselesaikan pada waktu kematian-Nya di Kayu Salib. Pada titik tersebut Yesus berhasil tanpa cacat melakukan hukum Taurat dan dikayu Salib juga Yesus menggenapi penghukuman dosa bagi manusia yang gagal melakukan hukum Taurat, dan salah satunya kegagalan orang percaya dalam melakukan hukum kedelapan. Dengan demikian melalui teladan tindakan Yesus maka hukum kedelapan bukan lagi sebagai sebuah hapalan bagi orang percaya, orang percaya melihat melalui teladan kehidupan Yesus, meskipun orang percaya tidak sama dengan Yesus Kristus, namun mengikuti teladan jauh lebih mudah daripada mengikuti sebuah hapalan.

Para Rasul memahami bahwa setelah penebusan Yesus maka keselamatan tidak bergantung lagi pada perbuatan atau tindakan melakukan Hukum Taurat. ${ }^{38}$ Calvin menyatakan bahwa hukum moral yang mengatur kehidupan manusia tetap dilakukan, tetapi dengan prinsip bukan untuk pembenaran melainkan sebagai respon

36Donald W. Burdick, "Markus," in The Wycliffe Bible Commentary, ed. Charles F. Pfeiffer and Everett F. Harrison, vol. 3(Malang: Gandum Mas, 2008), 183.

${ }^{37}$ Merrill C. Tenney, Survei Perjanjian Baru (Malang: Gandum Mas, 2009), 277.

${ }^{38}$ Douglas J. Moo, “'Law,' 'Works of the Law,' and Legalism in Paul," Westminster Theological Journal 45, no. 1 (1983): 73-100, http://library.mibckerala.org/. 
atas anugerah yang diterima dari karya penebusan Yesus Kristus. ${ }^{39}$ Namun apakah Para Rasul akhirnya mengabaikan Hukum tersebut?. Bagaimanakah memaknai hukum tersebut dalam konteks penebusan Yesus?. Kisah Para Rasul 5: 1-11, peristiwa Ananias dan Safira menunjukkan tindakan ketidakjujuran yang berbuah pencurian, meskipun hasil penjualan itu hak mereka, ketidakjujuran membuat status mereka mencuri apa yang harusnya diberikan kepada para Rasul. Konsekuensi tindakan tersebut berujung pada kematian Ananias dan Safira. Dengan demikian tindakan Ananias dan Safira telah melanggar kekudusan hidup dan kekudusan nama Tuhan. Prinsip pelanggaran tersebut sama dengan apa yang telah ditetapkan dalam Perjanjian Lama, bahwa hukum kedelapan adalah hukum yang memiliki nilai kekudusan.

Roma 11: 36 menyatakan bahwa segala sesuatu adalah dari Dia dan oleh Dia dan kepada Dia, bagi Dialah kemuliaan sampai selama-lamanya. Ayat tersebut menunjukkan bahwa hormat dan kemuliaan hanya diberikan kepada Allah. Ada istilah bahwa manusia mencuri kemuliaan Allah?. Benarkah manusia mampu mencuri kemuliaan Allah?.Dalam kaitannya dengan hukum Taurat rasul Paulus dalam Roma 2: 21 menegur penyimpangan pelaksanaan hukum Taurat. Paulus melihat kegagalan pengajar hukum Taurat. Paulus melihat mereka yang mengajar 'jangan mencuri' justru jatuh ke dalam dosa mencuri, dalam konteks tersebut rasul Paulus mengingatkan bahwa hanya ada kegagalan dalam melakukan hukum Taurat, sekalipun manusia bisa mengajarkan namun tetap gagal melakukan dengan sempurna. Dalam Roma 13: 9 rasul Paulus meneruskan apa yang telah diajarkan oleh Yesus bahwa kasih adalah kegenapan dalam melakukan hukum Taurat. Dengan demikian ada sebuah pengkontrasan antara jangan mencuri dan mengasihi. Selanjutnya Efesus 4: 28 mencatat bahwa orang yang mencuri janganlah ia mencuri lagi, frasa tersebut menunujukkan adanya kesempatan bagi manusia yang jatuh ke dalam dosa mencuri untuk tidak mencuri lagi, kalimat selanjutnya menunjukkan sebuah sikap yang kontras antara mencuri dengan bekerja dan membagikan sesuatu kepada yang kekurangan. Teks tersebut dituliskan dalam konteks mengenai manusia baru. ${ }^{40}$ Paulus menyampaikan sebuah pesan bahwa kasih karunia dari Yesus Kristus memberikan kesempatan dan pembaharuan hidup untuk bisa melakukan hukum kedelapan.

${ }^{39}$ Calvin, Institutio: Pengajaran Agama Kristen, 89-90.

${ }^{40}$ Thomas A. Hoffman, "Book Reviews: Brian A. Haggerty, Out of the House of Slavery: On the Meaning of the Ten Commandments. New York: Paulist Press, 1978. 158 Pp., \$2.95," Biblical Theology Bulletin: Journal of Bible and Culture 8, no. 4 (November 1978): 191-191, accessed September 6, 2020, http://journals.sagepub.com/doi/10.1177/014610797800800410. 
Rasul Paulus dalam surat Filemon meminta agar Filemon menerima kembali Onesimus. Dalam ayat 18 menyatakan bahwa Onesimus telah merugikan Filemon dan ada indikasi Onesimus melakukan pencurian. Dalam konteks tersebut tindakan pencurian Onesimus tidak langsung mengalami konsekuensi serius, namun justru Onesimus bisa berubah melalui pelayanan Paulus. Hal tersebut menunjukkan adanya problematika relasi saat seseorang melakukan tindakan mencuri. Namun setelah penebusan Kristus ada pengampunan dan pemulihan bagi personalitas yang gagal melakukan hukum tersebut. Ekspresi kasih semakin meluap ketika manusia orang percaya gagal melakukan hukum tersebut, namun pembaharuan hidup juga terjadi oleh karena kasih karunia Allah. Rasul Petrus dalam suratnya menasehati orang percaya diperantauan yang mengalami penderitaan, agar tidak menderita karena perbuatan dosa salah satunya mencuri (1Ptr. 4: 15). Dalam Wahyu 9:21 menyatakan bahwa banyak manusia pada akhir zaman tidak bertobat dari dosa pencurian. Dengan demikian mengharapkan semua manusia berhenti dari dosa mencuri adalah hal yang sulit, karena dosa tersebut terus berlanjut dan menjadi salah satu tanda orang yang tidak akan mendapat bagian dalam Kerajaan Allah (1 Kor. 6: 10).Perjanjian Baru tidak hanya memberikan arahan jangan mencuri tetapi memberikan solusi yaitu hidup bekerja keras.

Ungkapan figuratif tentang pencuri juga memberikan penekanan secara eskatologis. Pencuri yang datang tiba-tiba adalah ungkapan figuratif yang digunakan untuk kedatangan Yesus Kristus kedua kali (Mrk. 13: 33-37) dan karakteristik dari Iblis (Mat. 13: 19; Mrk. 4: 15; Luk. 8: 12). Kedua pengambaran secara figuratif tersebut sama-sama menekankan prinsip berjaga-jaga secara rohani. Berjaga menanti kedatangan Tuhan Yesus dan berjaga agar kebenaran yang orang percaya miliki tidak hilang dicuri oleh Iblis. Pernyataan bahwa yang dipilih ke dalam keselamatan tidak akan hilang menunjukkan jaminan perlindungan dari Allah kepada iman orang percaya, dengan demikian orang percaya siap menderita dan menghadapi kesulitan demi mempertahankan iman. Dunia tidak bisa mengambil iman orang percaya, karena Roh Kudus yang menjaga iman tersebut (Lih. Mat. 18: 14; Ef. 1: 14). Puncak penyataan kepemilikan Allah atas orang-orang pilihan tergenapi pada waktu kedatangan Yesus yang kedua kali (Mat. 24: 30-31) dan pada waktu orang percaya hidup di Langit dan Bumi yang baru (Why. 21: 1-4). Van Gemeren menuliskan bahwa puncak sejarah penebusan direalisasikan pada kedatangan Yesus Kristus yang kedua kali. Seluruh isi Firman Tuhan akan direlevansikan dalam prinsip Theosentris. Dalam kehidupan di Bumi dan langit baru segala sesuatu baik kasih, sukacita, kedamaian dan kesejahteraan hanya berpusat kedapa Allah Tritunggal. Pemikiran demikian mempengaruhi relevansi terhadap hukum kedelapan, dalam realitas bumi dan langit yang baru hukum kedelapan juga akan ditunjukkan dalam sebuah relevansi baru 
yaitu kasih kepada Allah Tritunggal. Iblis yang digambarkan sebagai pencuri firman juga akan tidak memiliki kuasa apa pun dihadapan penghakiman Allah, sehingga orang percaya memperoleh kemenangan terhadap penghakiman dari hukum kedelapan karena kasih Allah. ${ }^{41}$ Dengan demikian hukum Taurat kedelapan tetap direalisasikan dalam konteks kehidupan kekekalan dengan bentuk yang sempurna yaitu kasih. Prinsip demikian sejalan dengan apa yang telah dijelaskan Tuhan Yesus mengenai inti dari seluruh hukum Taurat yaitu kasih akan Allah dan kasih kepada sesama.

Hukum kedelapan dalam keluaran 20: 15 yaitu "jangan mencuri." Hukum tersebut adalah pemberian Allah kepada umat Israel melalui Musa. Hukum kedelapan adalah bagian dari Hukum Taurat. Hukum kedelapan dalam perkembangan sejarah kehidupan umat Israel tidak mengalami perkembangan makna. Dalam pembahasan memperlihatkan bahwa dalam setiap sejarah sesungguhnya Allah telah memberikan makna hukum tersebut secara absolut, yaitu perintah jangan mencuri, memiliki makna sebagai tindakan mengambil hak orang lain tanpa ijin dan tidak memberikan hak orang lain yang pada prinsipnya ialah melaksankan kasih kepada sesama. Perubahan yang terjadi dalam perkembangan sejarah Israel ialah realisasi Hukum Kedelapan. Pertama, dalam Kitab-kitab Pentateukh hukum kedelapan direalisasikan dalam konteks material, praktis, moral dan spirtual. Kedua, dalam Kitab-kitab Sejarah di Perjanjian Lama menunjukkan hukum tersebut direalisasikan dalam konteks praktis, material, non material, moral dan spiritual. Ketiga, dalam Kitab-kitab Puisi hukum tersebut direalisasikan dalam kontekspraktis, material, non material, moral, spiritual dan karakter. Keempat, dalam Kitab-kitab Nabi-nabi hukum tersebut direalisasikan dalam kaitannya dalam hal praktis, material, non material, moral, spiritual, dosa, ceremonial dan hari Tuhan. Kelima, dalam konteks Perjanjian Baru yaitu secara khusus dalam Kitab-kitab Injil hukum kedelapan direalisasikan dan digenapi serta dilaksanakan dengan sempurna oleh Yesus Kristus, baik dalam hal praktis, materi, non materi, moral, spiritual, dosa, ceremonial dan eskatologis. Para Rasul dalam tulisannya hanya menegaskan kembali realisasi hukum kedelapan di dalam dan Yesus Kristus.Puncak penebusan adalah pemulihan segala sesuatu yang dikerjakan Allah pada waktu kedatangan Yesus yang kedua kali (paraousia). Dalam pemulihan tersebut orang percaya akan tinggal bersama di langit dan bumi yang baru. Sehingga pemahaman hukum kedelapan menyangkut pemahaman pada masa kini (presentis) dan masa depan (futurist). Secara presentis ada banyak penerapan kategori dalam hal mencuri yaitu mencuri milik orang lain, mencuri waktu (Pkh. 3: 115; Kol. 4:5; Ibr. 5:12; 1Ptr. 4:2), tidak mengembalikan barang yang dipinjam (Maz. 37:21), mencuri dengan timbangan (Im. 19:35-36; Ul. 25:13-16; Ams. 11:1; 20:10,23;

41VanGemeren, 503-504. 
20: 10,23; Yeh. 45: 10-12; Mik. 6: 10-11; Am. 8: 4-5), Korupsi (Luk. 3: 13; Yoh. 12: 6), menggeser batas tanah (Ul. 19: 14; 27: 17) dan menjadi penadah barang curian (Ams. 29: 24). Hukuman terhadap pencurian ganti rugi (Kel. 22: 1, 35-4), hukuman mati (Kel. 21: 16) dan hukuman dikehidupan yang akan datang (1Kor. 6: 10). Solusi butuh anugerah dan menguduskan diri (Ef. 4: 28).

Dalam Alkitab juga memberikan gambaran tindakan mencuri yang bukan materi. Iblis bisa dikatakan sebagai pencuri firman dalam ungkapan figuratif. Sama seperti gambaran Yeremia bahwa tindakan mencuri bukan hanya pada konteks materi, namun pada konteks non materi salah satunya pencurian firman oleh Nabinabi Palsu, hal tersebut menjadi gambaran figuratif kepada Iblis yang dinyatakan dalam perjanjian baru sebagai pencuri kebenaran. Arti mencuri tersebut dalam bentuk tidak menyatakan keberanan atau menyembunyikan kebenaran yang dinyatakan. Dalam beberapa penjelasan konsep eskatologis menggunakan ungkapan figuratif, yaitu gambaran seorang pencuri yang datang pada malam hari dan tidak diketahui. Kedatangan Tuhan Yesus diumpakan seperti pencuri, sehingga orang percaya selalu diingatkan untuk berjaga-jaga. Jika Allah menggunakan ungkapan figuratif pencuri untuk menjelaskan kedatangannya, apakah secara prinsip Allah melakukan tindakan sebagai pencuri dalam realisasi kedatangannya?. Penjelasan yang baik adalah Allah tidak mengakomodir prinsip pencuri sebagai realisasi tindakan kedatangan, tetapi perumpaan tersebut memfokuskan pada prinsip kewaspadaan karena tidak ada ciptaan yang tahu kapan kedatangan Yesus yang kedua kali. Secara rohani hukum tersebut dinyatakan melalui umat yang akan dimiliki oleh Yesus tidak dapat lagi dicuri oleh Iblis dan Kehidupan kerohanian di langit dan bumi yang baru tidak ada lagi sifat mencuri, karena apa yang paling sempurna telah dimiliki yaitu hidup kekal. Puncak kehidupan di langit dan bumi yang baru mentiadakan hasrat manusia untuk berfokus pada dosa (Why. 21: 1-4). Karena fokus manusia hanya kepada Allah Tritunggal.

\section{Kesimpulan}

Pemahaman terhadap hukum kedelapan memberikan implikasi secara praktis dalam kehidupan orang percaya pada masa kini. Hal tersebut ditunjukkan karena ada jaminan bahwa harta rohani yang sejati yaitu iman kepada Yesus Kristus tidak akan hilang meskipun Iblis, dunia dan penderitaan mencoba mencuri. Allah tidak pernah berhenti bekerja untuk memberikan jaminan dan perlindungan yang pasti akan keselamatan bagi orang pilihan. Mengikuti teladan dari karya Allah tersebut maka pada masa kini orang percaya hendaknya menerapkan sikap hidup selalu berjagajaga secara rohani. Orang percaya tidak perlu gelisah dan takut akan serangan dari Iblis yang selalu mencuri kebenaran Firman Tuhan, karena Tuhan telah memberikan 
firman-Nya di dalam Alkitab. Orang percaya hendaknya terus membaca dan merenungkan firman Tuhan untuk berjaga-jaga agar Iblis tidak mendapat kesempatan mencuri atau mengurangi atau menghilangkan pemahaman yang benar dari firman Tuhan.Orang percaya juga hendaknya tidak usah takut akan masa depan, karena masa depan yang sejati adalah hidup kekal bersama dengan Allah di Surga. Iblis meskipun terus mencuri kebenaran firman Tuhan, namun kemenangan orang percaya adalah pasti, karena Allah memelihara dan melindungi kebenaran firmanNya. Allah Tritunggal adalah pemilik sejati atas segala ciptaan, sehingga segala ciptaan ada dalam kedaulatan-Nya, maka penghiburan sejati adalah jika hidup manusia dimiliki oleh Allah Tritunggal. Pada konteks masa kini kesempurnaan hukum tersebut hanya terealisasi di dalam dan melalui Yesus Kristus, namun pada puncak karya penebusan kesempurnaan hukum kedelapan baru terealisasi secara menyeluruh kepada umat pilihan di bumi dan langit yang baru, dan hukum tersebut dikenal dengan kasih kepada Allah dan sesama.

\section{Referensi}

Asali, Budi. "10 Hukum Tuhan: Hukum Kedelapan." Golgothaministry.org. Golgotha Ministry. Accessed November 2020. http://www.golgothaministry.org/artikel/pengajaran_10hukum08.htm.

Berkhof, Louis. Principles of Biblical Interpretation. Grand Rapids, 1981. 137.

Brown, Francis. In The New Brown Driver Briggs Gesenius Hebrew And English Lexicon, 158. Lafayette: Associated Publishers And Authors. INC, 1978.

Brown, Francis, S.R. Driver, and Charles A. Briggs, eds. The New Brown Driver Briggs Gesenius Hebrew And English Lexicon With An Apendix Containing The Biblical Aramic. Lafayette: Associated Publishers And Authors. INC, 1978.

Burdick, Donald W. "Markus." In The Wycliffe Bible Commentary, edited by Charles F. Pfeiffer and Everett F. Harrison, 3:183. Malang: Gandum Mas, 2008.

Cairns, David S. "The Person of Jesus Christ." The Expository Times 24, no. 3 (December 1912): 104-109. Accessed September 6, 2020. http://journals.sagepub.com/doi/10.1177/001452461202400302.

Calvin, Yohanes. Institutio: Pengajaran Agama Kristen. Jakarta: BPK Gunung Mulia, 2011. 
Christie Kusnandar. "Sepuluh Perintah Tuhan Bagian Kedua: Kasih Terhadap Manusia Dalam Tinjauan Etika Kristen." Jurnal Ilmiah Methonomi 3, no. 2 (2017): 7382.

Eichrodt, Walther. "The Law and the Gospel: The Meaning of the Ten Commandments in Israel and for Us." Interpretation: A Journal of Bible and Theology 11, no. 1 (January 1957): 23-40. Accessed September 6, 2020. http://journals.sagepub.com/doi/10.1177/002096435701100102.

Elliger, Karl, and Wilhelm Rudolph, eds. Perjanjian Lama Ibrani - Indonesia. Jakarta: LAI, 2016. 119.

Foeut, Fadilah Binti Ung. "Analisis Terhadap Konsep Dan Kedudukan Ten Commandements Dalam Agama Yahudi." UIN Sultan Syarif Riau, 2010. Accessed September 5, 2020. http://repository.uinsuska.ac.id/10725/1/2010_201023PAG.pdf.

GARSIEL, MOSHE. "The Story of David and Bathsheba: A Different Approach." The Catholic Biblical Quarterly 55, no. 2 (1993): 244-262. Accessed September 6, 2020. http://www.jstor.org/stable/43721228.

Guthrie, Donald. "Yohanes." In Tafsiran Alkitab Masa Kini, translated by W.B. Sijabat, 3:302. Jakarta: YKBK, 1994.

Harrison, Everett F. "Yohanes." In The Wycliffe Bible Commentary, edited by Charles F. Pfeiffer, 3:354. Malang: Gandum Mas, 2008.

Hasel, Gerhard F. Teologi Perjanjian Lama. Revisi. Malang: Gandum Mas, 2006. 167.

Hoffman, Thomas A. "Book Reviews: Brian A. Haggerty, Out of the House of Slavery: On the Meaning of the Ten Commandments. New York: Paulist Press, 1978. 158 Pp., \$2.95." Biblical Theology Bulletin: Journal of Bible and Culture 8, no. 4 (November 1978): 191-191. Accessed September 6, 2020. http://journals.sagepub.com/doi/10.1177/014610797800800410.

Johnson, Philip C. “Keluaran.” In The Wyclife Bible Commentary, 1:204. 1st ed. Malang: Gandum Mas, 2011.

Jr, David M. Howard. "Joshua." In The New American Commentary, edited by E. Ray Clendenen and Kenneth A. Mathews, 5:194. Nashville: Broadman \& Holman Publishers, 1998. 
Kelly, Page H. Ibrani Biblikal. 2nd ed. Surabaya: Momentum, 2018.

Kent, Homer A. "Matius." In The Wycliffe Bible Commentary, edited by Everett F. Harrison and Charles F. Pfeiffer, 3:35. Malang: Gandum Mas, 2008.

-_- "Matius." In The Wycliffe Bible Commentary, edited by Everett F. Harrison and Charles F. Pfeiffer, 3:89. Malang: Gandum Mas, 2008.

Marshall, J.T. "The Theology of Malachi." The Expository Times 7, no. 3 (December 1895): 125-127. Accessed September 6, 2020. http://journals.sagepub.com/doi/10.1177/001452469500700308.

Matalu, Muriwali Yanto. Dogmatika Kristen. last Edition. Malang: GKKR, 2017. 773.

Moo, Douglas J. “Law,' 'Works of the Law,' and Legalism in Paul." Westminster Theological Journal 45, no. 1 (1983): 73-100. http://library.mibckerala.org/.

Murtadin, Kafirun. "Yesus Maling Keledai." ..Com. Murtadinkafirun. Last modified February 10, 2011. Accessed September 5, 2020. https://murtadinkafirun.forumotion.com/t12990-yesus-maling-keledai.

Nazir, Mohamas. Metode Penelitian. Jakarta: Ghalia Indonesia, 1998. 64.

O'connor, Kathleen M. "The Prophet Jeremiah and Exclusive Loyalty to God." Interpretation: A Journal of Bible and Theology 59, no. 2 (April 2005): 130-140. Accessed September 6 , 2020. http://journals.sagepub.com/doi/10.1177/002096430505900203.

Paddison, Angus. "15th March: 3rd in Lent: The Resurrection and the Ten Commandments Exodus 20:1-17 Psalm 191 Corinthians 1:18-25 John 2:13-22." The Expository Times 120, no. 5 (February 2009): 243-245. Accessed September

6 , 2020. http://journals.sagepub.com/doi/10.1177/0014524608101114.

Pratt, Richard L. He Gave Us Stories. Surabaya: Momentum, 2005.

Rast, Walter E. "Book Review: Isaiah and the Deliverance of Jerusalem A Study of the Interpretation of Prophecy in the Old Testament." Interpretation: A Journal of Bible and Theology 35, no. 4 (October 1981): 423-424. Accessed September 6, 2020. http://journals.sagepub.com/doi/10.1177/002096438103500414. 
Ridderbos, Herman N. Biblical and Theological Studies, Redemptive History and The New Testament Scriptures. Philipsburg: Presbyterian and Reformed Publishing Company, n.d. 49.

_—_. Injil Yohanes Suatu Tafsiran Theologis. Surabaya: Momentum, 2012.

Singgih, Emanuel Gerrit. Dua Konteks: Tafsir-Tafsir Perjanjian Lama Sebagai Respons Atas Perjalanan Reformasi Di Indonesia. Jakarta: BPK Gunung Mulia, 2009. XXii.

Soho, Violent. Violent Soho - Jesus Stole My Girlfriend. You Tube, Music. UMG Recordings, n.d. Accessed September 5, 2020. https://www.youtube.com/watch?v=kzrAfkyq-xM.

Supriadi, M.N. Menghadapi Relativitas Kehidupan: Sebuah Refleksi Kehidupan Ayub Dalam Penderitaan (Ayub 1:1-5; 13-22, 2:7-10, 42:10-17). Bengkulu: Permata Rafflesia, 2020. https://books.google.co.id/books?id=mznJDwAAQBAJ.

Sutanto, Hasan. Perjanjian Baru Interlinear Dan Konkordansi Jilid 1. Jakarta: LAI, 2010. 108.

———. Perjanjian Baru Interlinear Dan Konkordansi Jilid 2. Jakarta: LAI, 2010. 585.

Tenney, Merrill C. Survei Perjanjian Baru. Malang: Gandum Mas, 2009. 277.

VanGemeren, Willem. Progress Penebusan: Kisah Keselamatan Dari Penciptaan Sampai Yerusalem Baru. Surabaya: Momentum, 2016. 17-19.

- - - In Progress Penebusan: Kisah Penebusan dari Penciptaan sampai Yerusalem Baru, 18. Surabaya: Momentum, 2016.

Wenham, David. "Jesus and the Law: An Exegesis on Matthew 5: 17-20." Themelios 4, no. 3 (1979): 92-96.

Zai, Iman Nuel, and Thuan Ong. "Memahami Konsep Penebusan Dalam Hukum Taurat Dan Penggenapannya Dalam Diri Yesus Kristus." Pondok Daud: Jurnal Teologi Kristen 6, no. 1 (2020): 1-7. http://ejournal.sttpkmedan.ac.id/index.php/pondokdaud/article/view/3/2. 